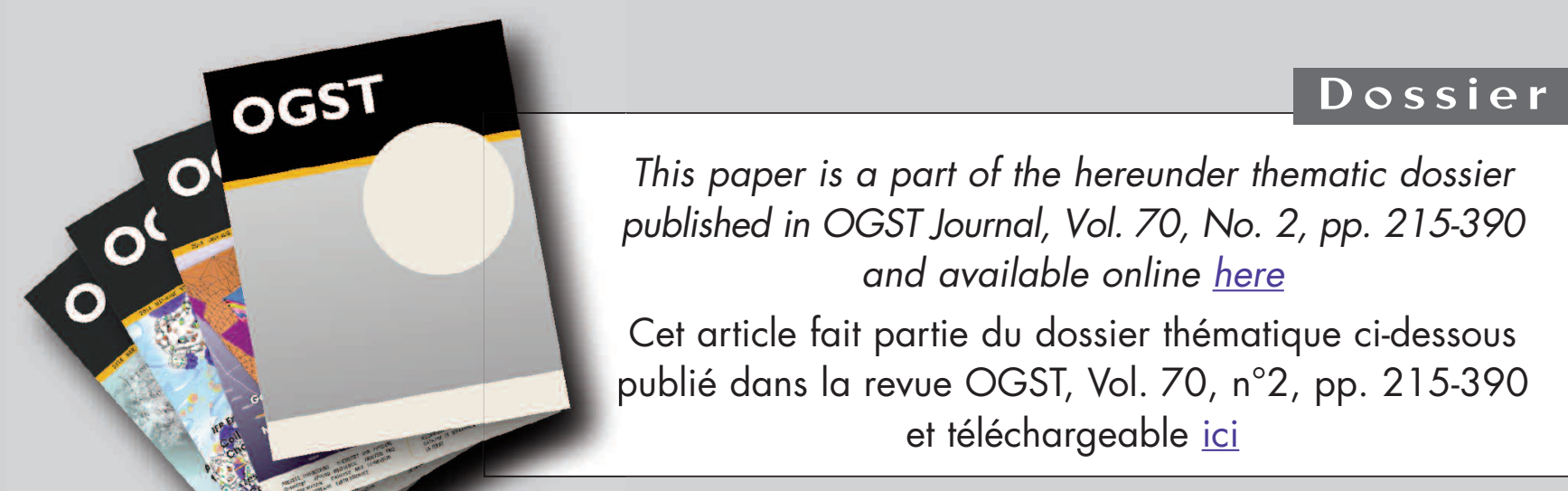

DOSSIER Edited by/Sous la direction de : B. Dewimille

Fluids-Polymers Interactions: Permeability, Durability

Interactions fluides polymères : perméabilité, durabilité

Oil \& Gas Science and Technology - Rev. IFP Energies nouvelles, Vol. 70 (2015), No. 2, pp. 215-390

Copyright (C) 2015, IFP Energies nouvelles

$215>$ Tribute to Yves Chauvin Hommage à Yves Chauvin

S. Candel and 0 . Appert

$219>$ Editorial

G. Kimmerlin

227 > Gas Permeation in Semicrystalline Polyethylene as Studied by Molecular Simulation and Elastic Model

Perméation de gaz dans le polyéthylène semi-cristallin par simulation moléculaire et modèle élastique

P. Memari, V. Lachet and B. Rousseau

237 > Reinforcement of the Gas Barrier Properties of Polyethylene and Polyamide Through the Nanocomposite Approach: Key Factors and Limitations

Renforcement des propriétés barrière aux gaz de matrices polyéthylène et polyamide par l'approche nanocomposite : facteurs clés et limitations E. Picard, J.-F. Gérard and É. Espuche

251 > Diffuso-Kinetics and Diffuso-Mechanics of Carbon Dioxide / Polyvinylidene Fluoride System under Explosive Gas Decompression: Identification of Key Diffuso-Elastic Couplings by Numerical and Experimental Confrontation

Cinétique de diffusion et comportement diffuso-mécanique du système dioxide de carbone / polyfluorure de vinylidène sous décompression explosive de gaz : identification des couplages diffuso-élastiques majeurs par confrontation numérique et expérimentale

J.-C. Grandidier, C. Baudet, S. A. E. Boyer, M.-H. Klopffer and L. Cangémi

267 > Characterization of Polymer Layered Silicate Nanocomposites by Rheology and Permeability Methods: Impact of the Interface Quality

Caractérisation de nanocomposites polymère silicate par des méthodes de rhéologie et de perméabilité : rôle de la qualité de l'interface

R. Waché, M.-H. Klopffer and S. Gonzalez

$279>$ Evaluation of Long Term Behaviour of Polymers for Offshore Oil and Gas Applications

Durabilité des polymères pour application pétrolière offshore

P.-Y. Le Gac, P. Davies and D. Choqueuse

$291>$ Development of Reactive Barrier Polymers against Corrosion for the Oil and Gas Industry: From Formulation to Qualification through the Development of Predictive Multiphysics Modeling

Développement de matériaux barrières réactifs contre la corrosion pour l'industrie pétrolière : de la formulation à la qualification industrielle en passant par le développement de modèles multiphysiques prédictifs

X. Lefebvre, D. Pasquier, S. Gonzalez, T. Epsztein, M. Chirat and F. Demanze
$305>$ Development of Innovating Materials for Distributing Mixtures of Hydrogen and Natural Gas. Study of the Barrier Properties and Durability of Polymer Pipes

Développement de nouveaux matériaux pour la distribution de mélanges de gaz naturel et d'hydrogène. Étude des propriétés barrière et de la durabilité de tubes polymères

M.-H. Klopffer, P. Berne and É. Espuche

317 > New Insights in Polymer-Biofuels Interaction

Avancées dans la compréhension des interactions polymères-biocarburants E. Richaud, F. Diouani, B. Fayolle, J. Verdu and B. Flaconneche

$335>$ Biofuels Barrier Properties of Polyamide 6 and High Density Polyethylene Propriétés barrière aux bio essences du polyamide 6 (PA6) et du polyéthylène haute densité (PEHD)

L.-A. Fillot, S. Ghiringhelli, C. Prebet and S. Rossi

353 > Permeability of EVOH Barrier Material used in Automotive Applications: Metrology Development for Model Fuel Mixtures

Perméabilité d'un matériau barrière EVOH utilisé dans des applications automobiles : développement métrologique pour des mélanges modèles de carburants

J. Zhao, C. Kanaan, R. Clément, B. Brulé, H. Lenda and A. Jonquières

367 > Effects of Thermal Treatment and Physical Aging on the Gas Transport Properties in Matrimid ${ }^{\circledR}$

Les effets du traitement thermique et du vieillissement physique sur les caractéristiques du transport au gaz dans le Matrimid ${ }^{\circledR}$

L. Ansaloni, M. Minelli, M. Giacinti Baschetti and G. C. Sarti

381 > Separation of Binary Mixtures of Propylene and Propane by Facilitated Transport through Silver Incorporated Poly(Ether-Block-Amide) Membranes Séparation de mélanges binaires de propylène et de propane par transport au travers des membranes de poly(éther-blocamide) incorporant de l'argent R. Surya Murali, K. Yamuna Rani, T. Sankarshana, A. F. Ismail and S. Sridhar 


\title{
Separation of Binary Mixtures of Propylene and Propane by Facilitated Transport through Silver Incorporated Poly(Ether-Block-Amide) Membranes
}

\author{
R. Surya Murali ${ }^{1,4}$, K. Yamuna Rani ${ }^{2}$, T. Sankarshana ${ }^{3}$, A.F. Ismail ${ }^{4}$ and S. Sridhar ${ }^{1 *}$ \\ ${ }^{1}$ Membrane Separations Group, Chemical Engineering Division, Indian Institute of Chemical Technology, Hyderabad 500607 - India \\ 2 Process Dynamics and Control Group, Chemical Engineering Division, Indian Institute of Chemical Technology, Hyderabad 500607 - India \\ ${ }^{3}$ College of Technology, Osmania University, Hyderabad 500607 - India \\ ${ }^{4}$ Advanced Membrane Technology Research Centre (AMTEC), Universiti Teknologi Malaysia, 81310 Skudai, Johor - Malaysia \\ e-mail: suryaracha@yahoo.co.in - kyrani@iict.res.in - tsankarshana@yahoo.com - afauzi@utm.my - sridhar11in@yahoo.com
}

* Corresponding author

\begin{abstract}
The separation of propylene and propane is a challenging task in petroleum refineries due to the similar molecular sizes and physical properties of two gases. Composite Poly(etherblock-amide) (Pebax-1657) membranes incorporated with silver tetra fluoroborate $\left(A g B F_{4}\right)$ in concentrations of $0-50 \%$ of the polymer weight were prepared by solution casting and solvent evaporation technique. The membranes were characterized by Scanning Electron Microscopy (SEM), Fourier Transform InfraRed (FTIR) and wide-angle X-Ray Diffraction (XRD) to study surface and cross-sectional morphologies, effect of incorporation on intermolecular interactions and degree of crystallinity, respectively. Experimental data was measured with an indigenously built high-pressure gas separation manifold having an effective membrane area of $42 \mathrm{~cm}^{2}$. Permeability and selectivity of membranes were determined for three different binary mixtures of propylene-propane at pressures varying in the range 2-6 bar. Selectivity of $\mathrm{C}_{3} \mathrm{H}_{6} / \mathrm{C}_{3} \mathrm{H}_{8}$ enhanced from 2.92 to 17.22 and 2.11 to 20.38 for $50 / 50$ and $66 / 34 \mathrm{C}_{3} \mathrm{H}_{6}+\mathrm{C}_{3} \mathrm{H}_{8}$ feed mixtures, respectively, with increasing loading of $\mathrm{AgBF}_{4}$. Pebax membranes incorporated with $\mathrm{AgBF}_{4}$ exhibit strong potential for the separation of $\mathrm{C}_{3} \mathrm{H}_{6} / \mathrm{C}_{3} \mathrm{H}_{8}$ mixtures in petroleum refineries.
\end{abstract}

Résumé - Séparation de mélanges binaires de propylène et de propane par transport au travers des membranes de poly(éther-bloc-amide) incorporant de l'argent - La masse moléculaire et les propriétés physiques similaires du propylène et du propane rendent problématique la séparation des deux gaz dans les raffineries de pétrole. Des membranes composites de poly (éther-bloc-amide) (Pebax-1657) incorporant du tétrafluoroborate d'argent $\left(\mathrm{AgBF}_{4}\right)$ dans des concentrations massiques allant de 0 à $50 \%$ ont été préparées par enduction et évaporation du solvant. Les membranes ont été caractérisées par Microscopie Électronique à Balayage (MEB), par spectroscopie InfraRouge à Transformée de Fourier (IRTF) et par diffractométrie de rayons $\mathrm{X}$ aux grands angles (DRX) afin d'étudier respectivement la morphologie de surface et transversale, l'impact de l'intégration d'AgBF4 sur les interactions intermoléculaires et le degré de cristallinité. Les données expérimentales ont été collectées dans une chambre de séparation à haute pression conçue spécialement ayant une surface effective de membrane de $42 \mathrm{~cm}^{2}$. La perméabilité et la sélectivité des membranes sont déterminées pour trois mélanges 
binaires de propylène-propane de ratios différents sous des pressions comprises entre 2 et 6 bar. En augmentant la charge d'AgBF4, la sélectivité entre $\mathrm{C}_{3} \mathrm{H}_{6}$ et $\mathrm{C}_{3} \mathrm{H}_{8}$ est améliorée et passe de 2,92 à 17,22 et de 2,11 à 20,38 pour des mélanges $\mathrm{C}_{3} \mathrm{H}_{6}+\mathrm{C}_{3} \mathrm{H}_{8}$ de ratio $50 / 50$ et 66/34, respectivement. Les membranes Pebax incorporant de $\mathrm{l}^{\prime} \mathrm{AgBF} \mathrm{F}_{4}$ présentent un fort potentiel pour les applications de séparation des mélanges de $\mathrm{C}_{3} \mathrm{H}_{6} / \mathrm{C}_{3} \mathrm{H}_{8}$ dans les raffineries de pétrole.

\section{INTRODUCTION}

Propylene/propane separation is one of commercially important process in petrochemical industry and petroleum refinery. Propylene is main resource for the production of polymers, acids, alcohols, esters, ethers and some other intermediates. Propane $\left(\mathrm{C}_{3} \mathrm{H}_{8}\right)$ and propylene $\left(\mathrm{C}_{3} \mathrm{H}_{6}\right)$ have similar molecular sizes and physical properties; hence separation of these two gases is complex. Many processes like absorption, adsorption and membrane techniques have been developed as an alternative to this separation [1-3]. Among all these, membrane separation, especially use of facilitated transport membranes, could be an alternative to distillation or complement the same by reducing the number of stages $[4,5]$.

Burns and Koros [6] had conducted a comprehensive review by evaluating all of the literature available until that period to define the upper bound relationship for $\mathrm{C}_{3} \mathrm{H}_{6} / \mathrm{C}_{3} \mathrm{H}_{8}$ separation. Nowadays, facilitated transport membranes utilize silver salt in appropriate polymer matrices, which have exhibited high performance for olefin/paraffin separation [7-10]. In our earlier work, $\mathrm{C}_{3} \mathrm{H}_{6}$ recovery using metal ion incorporated PolyPhenylene Oxide (PPO) and EthylCellulose (EC) membranes were reported [11, 12]. Silver salts like $\mathrm{AgBF}_{4}, \mathrm{AgNO}_{3}$, $\mathrm{AgClO}_{4}$ and $\mathrm{AgCF}_{3} \mathrm{SO}_{3}$ were dissolved in the polymer solution for synthesizing silver embedded membranes to enhance the separation properties. Mixtures of silver salts were also incorporated for achieving better separation [7]. Sunderrajan et al. [13] reported that the order of olefin solubility in blends containing $1 \mathrm{~mol}$ of silver ions per mole of Ethylene Oxide (EO) units is:

$$
\mathrm{AgBF}_{4}>\mathrm{AgCF}_{3} \mathrm{SO}_{3}>\mathrm{AgNO}_{3}
$$

Kim et al. [14] had investigated the role of the polymer matrix in facilitated olefin transport through polymer/ silver salt complex membranes, particularly its influence on the structure and interactions of polymer/silver salt complexes and hence on the interactions of silver ions with olefin molecules. It was found that the threshold concentration of silver salt for facilitated olefin transport depends on the polymeric ligand and decreases in the following order of amide $>$ ketone $>$ ester. Several researchers have been working using pure $\mathrm{C}_{3} \mathrm{H}_{6}$ and $\mathrm{C}_{3} \mathrm{H}_{8}$ gases to study the performance of polymeric membrane by incorporating metal complexes which facilitate the transport of $\mathrm{C}_{3} \mathrm{H}_{6}$.

Poly(ether-block-amide) resin is best known under the trademark Pebax and is a thermoplastic elastomer combining linear chains of the hard polyamide segments that provide mechanical strength with interspacing of flexible polyether segments that offer high permeability due to greater chain mobility of the ether linkage [15]. Crystalline amide block in Pebax functions as an impermeable phase, whereas the ether block acts as a permeable phase because of its high chain flexibility. Many researchers had worked with different grades of Pebax and different silver salts by varying degree of loading $[16,17]$. Pebax2533 consists of $80 \%$ amide and $20 \%$ ether groups, which allow high permeability and less resistance to plasticization. Pebax-4011 gives lower permeability due to the presence of only $57 \%$ soft ether block segment.

To counter these problems, Pebax-1657, constituted by $40 \%$ amide groups and $60 \%$ ether linkages, was selected as the base polymer for $\mathrm{AgBF}_{4}$ incorporation to evaluate propylene-propane separation performance in the present study. Silver salt was expected to undergo adequate solubilization within the matrix of this block copolymer in order to allow enhanced interaction with the unsaturated olefin gas. Membranes with different $\mathrm{AgBF}_{4}$ concentration in the polymer matrix were synthesized and characterized using SEM, FTIR and XRD studies. Experiments were conducted using these membranes in a permeability cell with propylene-propane mixtures of different compositions at varying feed pressures to determine the permeability and selectivity of each membrane for these cases, and also to find the $\mathrm{AgBF}_{4}$ concentration most suitable for the desired separation.

\section{MECHANISM OF FACILITATED TRANSPORT}

The facilitated transport membranes involve reversible complexation reaction in addition to the simple solution-diffusion mechanism. The penetrant dissolves in the membrane and then diffuses down the concentration gradient or it can react with the complexing agent or a carrier and then diffuse down the concentration gradient of the carrier-gas complex. The latter transport 


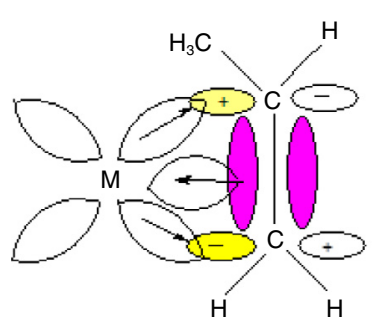

a)

Figure 1

a) Dewar-Chatt model of $\pi$-bond complexation, b) hypothetical structure of the $\mathrm{AgBF}_{4}$ complexation with $\mathrm{C}_{3} \mathrm{H}_{6}$ molecule in the polymeric matrix.

mechanism is not available to the saturated paraffin molecules such as $\mathrm{C}_{3} \mathrm{H}_{8}$, as they do not react with the complexing agent.

Figure 1 shows the metal-olefin bonding described by the Dewar-Chatt model and hypothetical structure of the $\mathrm{AgBF}_{4}$ complex with $\mathrm{C}_{3} \mathrm{H}_{6}$ molecule in the polymeric matrix. The complex is formed by double bonding of a silver atom with the olefin $[18,19]$. Both the metal and alkenes act as an electron donor and acceptor respectively in the complexation interaction. A $\sigma$ component of the bond results from overlap of the vacant outermost $s$ atomic orbital of the metal with the full $\pi$ (bonding) molecular orbital of the olefin. This new molecular orbital, formed by donation of electrons from olefin to metal, has electron density concentrated between the bond members. In $\mathrm{Ag}^{+}$ions, the outermost $s$ orbital is empty because the single electron present in the metal is lost upon ionization to $a+1$ valence. In nonionizing facilitators, the metal is often bound to be an electronegative atom that withdraws electron density from the metal, resulting in a partial positive charge and a substantially vacant outermost $s$ orbit. A $\pi$ component of the metalolefin bond is formed by back donation of electrons from the full outer $d$ atomic orbital of the metal to the $\pi^{*}$ (antibonding) molecular orbital of the olefin. The new molecular orbital has a nodal plane of electron density between the membranes of the bond.

\section{EXPERIMENTAL}

\subsection{Materials}

Commercially available Pebax-1657 was purchased from Atofina Chemicals, France, whereas PolyEtherSulfone (PES) powder was procured from Radel, USA. $\mathrm{AgBF}_{4}$ salt was supplied by Aldrich Chemical, USA. Ethanol,
DiMethylFormamide (DMF) and propionic acid were purchased from Loba Chemie, Mumbai, India. Gas mixture cylinders of $\mathrm{C}_{3} \mathrm{H}_{6}$ and $\mathrm{C}_{3} \mathrm{H}_{8}(50 / 50,66 / 34$ and 90/10 mole\%) were supplied by Bhoruka Gases Ltd., Bangalore, India, at filling pressures of 9 bar each. Deionized water was produced with a laboratory reverse osmosis system.

\subsection{Membrane Synthesis}

PES substrate of approximately 30000 molecular weight cutoff (MWCO) was prepared by procedure described elsewhere [20]. PES was dissolved in DMF for making $18 \% \mathrm{w} / \mathrm{v}$ solution and $3 \%$ propionic acid was added as additive. Homogeneous polymer solution was cast on a non-woven fabric, which was fixed on a glass plate. After casting, the glass plate was immersed in ice-cold water bath for 5-10 min to obtain ultra porous thin substrate. $\mathrm{AgBF}_{4}$ loaded Pebax membranes were prepared on PES substrate by solution casting and solvent evaporation technique.

A 4\% Pebax solution was prepared by adding polymer pellets to solvent mixture of $70 \%$ ethanol and $30 \% \mathrm{v} / \mathrm{v}$ water. The polymer was dissolved at $90^{\circ} \mathrm{C}$ with rigorous stirring maintained under constant reflux over a period of $6 \mathrm{~h} . \mathrm{AgBF}_{4}$ in proportion of 35,40 and $50 \%$ of the polymer weight was added to Pebax solution and kept for stirring. A small quantity of an oxidizing agent, commonly hydrogen peroxide, was added to stabilize the solution and prevent silver poisoning and silver loss. Without the addition of a stabilizing agent, polymer solutions containing silver salts turned black within a few hours, indicating that silver ions were being reduced to silver metal particles. Hydrogen peroxide was added for slowing down the reduction of silver ions to uncharged silver atoms. The bubble free solution was cast on PES substrate using a doctor's blade. The obtained Thin Film Composite (TFC) membrane was dried at ambient temperature $\left(30^{\circ} \mathrm{C}\right)$ for $3 \mathrm{~h}$ followed by vacuum drying for $24 \mathrm{~h}$ to remove residual solvent. Since it is difficult to accurately determine the exact thickness of the skin layer of a composite membrane, the authors carefully peeled off the top layer from the PES substrates in order to measure the effective thickness.

\subsection{Membrane Characterization}

The surface and cross-sectional morphology of Pebax and Ag-Pebax membranes were studied by SEM using a Hitachi S2150 microscope. To obtain smooth crosssection, the samples were cut in liquid nitrogen. FTIR spectra of Pebax and Ag-Pebax composite membranes 
were scanned between 400 and $3700 \mathrm{~cm}^{-1}$ using PerkinElmer-283B FTIR Spectrometer. A Siemens D 5000 powder X-ray diffractometer was used to study the solid-state morphology of Pebax and Ag-Pebax composite membranes. X-rays of $1.5406 \AA$ wavelengths were generated by a $\mathrm{CuK}-\alpha$ source. The angle $(2 \theta)$ of diffraction was varied from $0^{\circ}$ to $65^{\circ}$ to identify the crystal structure and intermolecular distances between the intersegmental chains.

\subsection{Permeability Studies}

A schematic diagram of the experimental setup to carryout permeability studies is shown in Figure 2. The gas permeation tests were conducted using an indigenously designed and fabricated permeation test cell made of Stainless Steel (SS) 316. The detailed description of test cell was given in our earlier publication [20]. Gas inlet and outlet ports were provided in the test cell for the transport of feed, permeate, retentate and carrier streams. The test cell contained a circular perforated plate affixed with a mesh to support membrane of effective area $42 \mathrm{~cm}^{2}$. All the tubes were made of $1 / 4^{\prime \prime}$ SS 316 . Needle valves (Swagelok, USA) with $1 / 4^{\prime \prime}$ SS 316 end connections were used to regulate the flow of inlet and outlet streams. Membrane is supported on a metallic disc across which feed flows. During permeability studies, permeate line is evacuated to remove air or residual gases present. However, evacuating feed line may tear/damage the membrane or make the edges of the membrane to get displaced from the rubber ' $O$ ' ring used for sealing the gas tight arrangement. Therefore, feed/permeate lines were flushed with the feed gas to remove the residual gas/air present inside. Permeability values were recorded only after steady state was reached or constant flux was attained during the experiments.

In the present work, experiments were conducted with three binary feed mixtures for testing, in which $\mathrm{C}_{3} \mathrm{H}_{6}$ is $50 \%, 66 \%$ and $90 \%$ and the remaining is $\mathrm{C}_{3} \mathrm{H}_{8}$. Since the permeate flow rate was considerable, carrier gas was not employed. Before each experiment, the permeate line was evacuated with a vacuum pump (Hindhivac, Bangalore, India) with the perforated plate support ensuring no membrane rupture. The feed and retentate lines cannot be evacuated and hence were flushed with the feed to remove residual air and ensure maximum purity of the gas inside the cell. Experiments were conducted over a feed pressure range of 2-6 bar at ambient temperature $\left(30 \pm 2{ }^{\circ} \mathrm{C}\right)$. Feed gas was introduced slowly into the upper chamber of the test cell by means of a needle valve with the outlet valve kept partially closed until the gauge indicated the desired pressure. Continuous

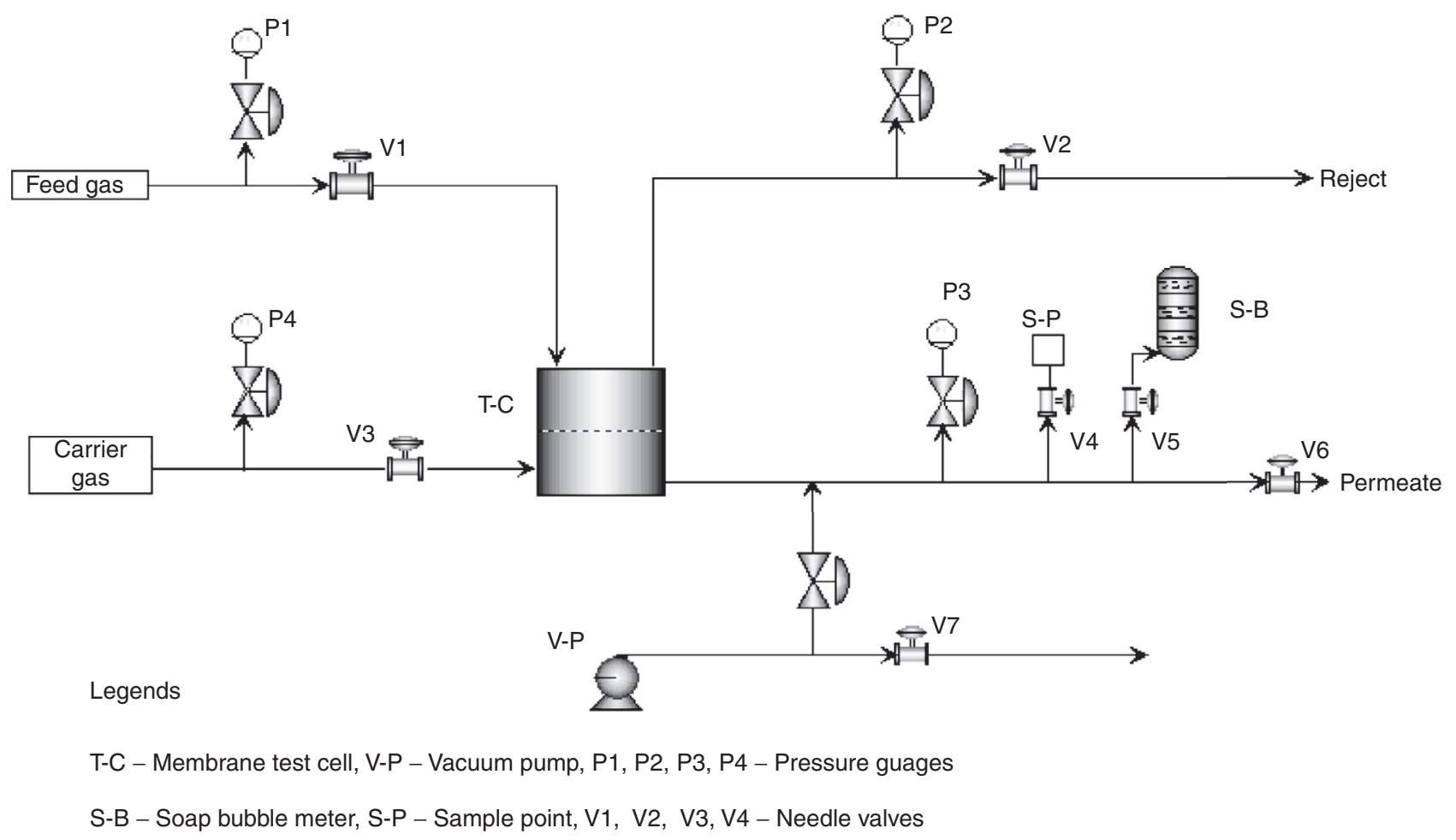

Figure 2

Schematic of high-pressure gas permeability manifold. 
flow of the gas in the feed chamber was maintained. Once steady state was attained, the flow rate of permeate and retentate were measured with the help of a soap bubble meter. Permeate side valve was kept open and flow rate was measured at atmospheric pressure (1 bar). Provision was made for online analysis by throttling respective individual valve of feed, permeate and retentate with a gas chromatograph equipped with a $30 \mathrm{ft}$ SP-1700 Chromosorb P-AW column (stationary phase: methyl cyano silicone) which gave complete resolution of $\mathrm{C}_{3} \mathrm{H}_{6}$ and $\mathrm{C}_{3} \mathrm{H}_{8}$ peaks. The chromatograph was operated with a thermal ionization detector and Helium was used as the carrier gas. The oven temperature was maintained at $60^{\circ} \mathrm{C}$. The degree of error while collecting experimental data is about $\pm 2 \%$ which also accounts for deviation in analytical method. As long as the membrane was not exposed to sunlight the permeability results obtained with different samples of the Ag loaded membranes were very consistent (reproducible) as long as the substrate porosity and selective layer thickness were kept fairly constant.

A binary feed gas, $F\left(\mathrm{~cm}^{3} / \mathrm{s}\right)$, with a mole fraction of $x_{f}$ entered the membrane test cell giving two streams-as outlet with gas which passed through the membrane denoted as permeate, $V\left(\mathrm{~cm}^{3} / \mathrm{s}\right)$, with a moles fraction of $y_{p}$; and non-permeating gas, $R\left(\mathrm{~cm}^{3} / \mathrm{s}\right)$, with a mole fraction of $x_{0}$.

The rate of permeation of species $A$, in binary mixture of $A$ and $B$, is given by:

$$
V y_{p}=\left(\frac{P_{A}^{\prime} A_{m}}{t}\right)\left(p_{h} x_{0}-p_{l} y_{p}\right)
$$

where $P_{A}^{\prime}$ is the permeability of $A$ in the membrane, $\mathrm{cm}^{3}(\mathrm{STP}) . \mathrm{cm} /\left(\mathrm{s} . \mathrm{cm}^{2} . \mathrm{cmHg}\right) ; A_{m}$ is membrane area, $\mathrm{cm}^{2} ; t$ is membrane thickness, $\mathrm{cm} ; p_{h}$ is the pressure in feed side, $\mathrm{cmHg} ; p_{l}$ is the pressure in the permeate side, cmHg.

A similar equation can be written for the component B:

$$
V\left(1-y_{p}\right)=\left(\frac{P_{B}^{\prime} A_{m}}{t}\right)\left(p_{h}\left(1-x_{0}\right)-p_{l}\left(1-y_{p}\right)\right)
$$

Permeability of species $i, P_{i}^{\prime}$, in the gas mixture is given by:

$$
P_{i}^{\prime}=\frac{y_{p} t}{A_{m}\left(x_{f} p_{h}-y_{p} p_{l}\right)}\left(\frac{273}{T}\right)\left(\frac{P_{a t m}}{76}\right)\left(\frac{d v}{d t}\right)
$$

where $P_{\text {atm }}$ is the atmospheric pressure, $(d v / d t)$ is the volumetric flow rate, $\mathrm{cm}^{3} / \mathrm{s}$.
The actual separation factor $\alpha$ is given by:

$$
\alpha=\frac{P_{A}^{\prime}}{P_{B}^{\prime}}
$$

\section{RESULTS AND DISCUSSION}

\subsection{Membrane Characterization}

\subsubsection{SEM}

Figures $3 \mathrm{a}$ and $\mathrm{c}$ show the surface morphology of pristine Pebax and $50 \mathrm{wt} \%$ Ag-Pebax membranes which are clear and homogeneous. Surface morphology of Ag-Pebax clearly shows a regular polymer surface without any particle clusters. It can be concluded that the added salt is completely solubilized in the polymer matrix. Cross-section of Pebax is shown in Figure 3b, which clearly reveals the presence of three layers in the TFC membrane. Top layer is the active Pebax, second layer is ultraporous PES substrate and the last layer is the non-woven polyester fabric support. Cross-sectional views of Ag-Pebax is illustrated in Figure 3d which reveals that Pebax containing $\mathrm{AgBF}_{4}$ partially penetrates into the ultraporous PES support and forms a thin but uniform selective dense layer over it.

\subsubsection{FTIR}

Figure 4 represents Fourier Transform InfraRed (FTIR) spectra of Pebax and Ag-Pebax membranes. In Pebax (Fig. 4a), the characteristic peaks at 1599 and $1058 \mathrm{~cm}^{-1}$ represent $-\mathrm{C}=\mathrm{C}$ and $-\mathrm{C}-\mathrm{O}-$ stretching vibrations respectively. Two more peaks at 1641 and $3299 \mathrm{~cm}^{-1}$ indicate the presence of $\mathrm{H}-\mathrm{N}-\mathrm{C}=\mathrm{O}$ and $\mathrm{N}-\mathrm{H}$ groups respectively. The stretching vibration at $2940 \mathrm{~cm}^{-1}$ indicates the presence of aliphatic $-\mathrm{C}-\mathrm{H}$. The $\mathrm{C}=\mathrm{O}$ stretching in amide group of Pebax is constituted of two types, the free amide $\mathrm{C}=\mathrm{O}$ peak at $1657 \mathrm{~cm}^{-1}$ and the hydrogen bonded amide peak at $1640 \mathrm{~cm}^{-1}$. The characteristic peaks of Ag-Pebax membranes are similar to pristine Pebax, which may be probably due to the suppression of vibration effects caused by silver salt with polymer matrix. Vibrations at $1599 \mathrm{~cm}^{-1}$ and $3060 \mathrm{~cm}^{-1}$, caused by $\mathrm{C}=\mathrm{C}$ stretching, differ a little from plane Pebax, steepness of peak decreases with increasing salt loading. This could be due to temporary bonding between $\mathrm{Ag}^{+}$and $\mathrm{C}=\mathrm{C}$. The metal ligand interaction bands are seen distinctly in the low frequency region (600-400 $\left.\mathrm{cm}^{-1}\right)$. It also reveals that the $\mathrm{C}=\mathrm{O}$ vibrations of $\mathrm{HN}-\mathrm{C}=\mathrm{O}$ groups at $1641 \mathrm{~cm}^{-1}$ decrease with increasing $\mathrm{AgBF}_{4}$. This decrease indicates the loosening of the 

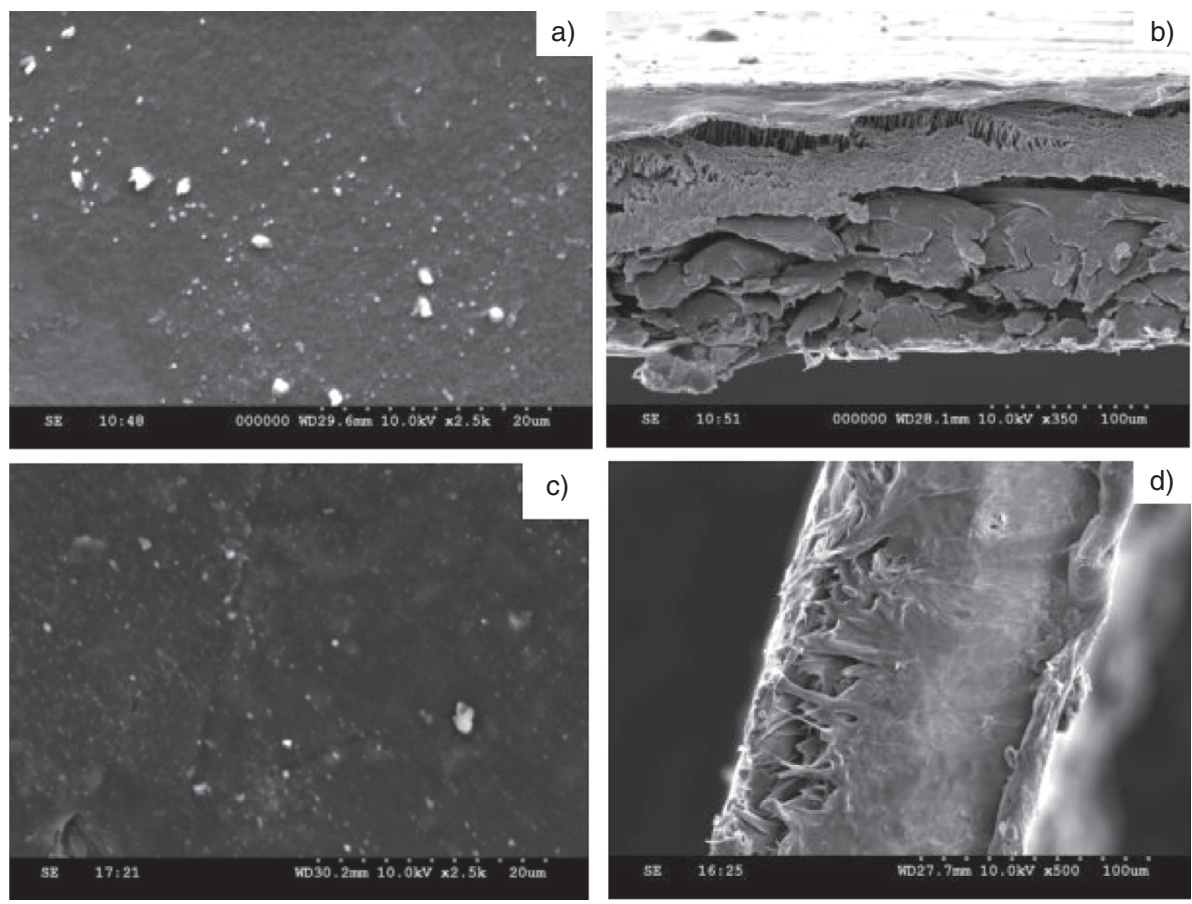

Figure 3

SEM pictures representing: a) surface of Pebax, b) cross-section of Pebax, c) surface of $50 \mathrm{wt} \% \mathrm{Ag}$-Pebax, d) cross-section of $50 \mathrm{wt} \%$ Ag-Pebax.

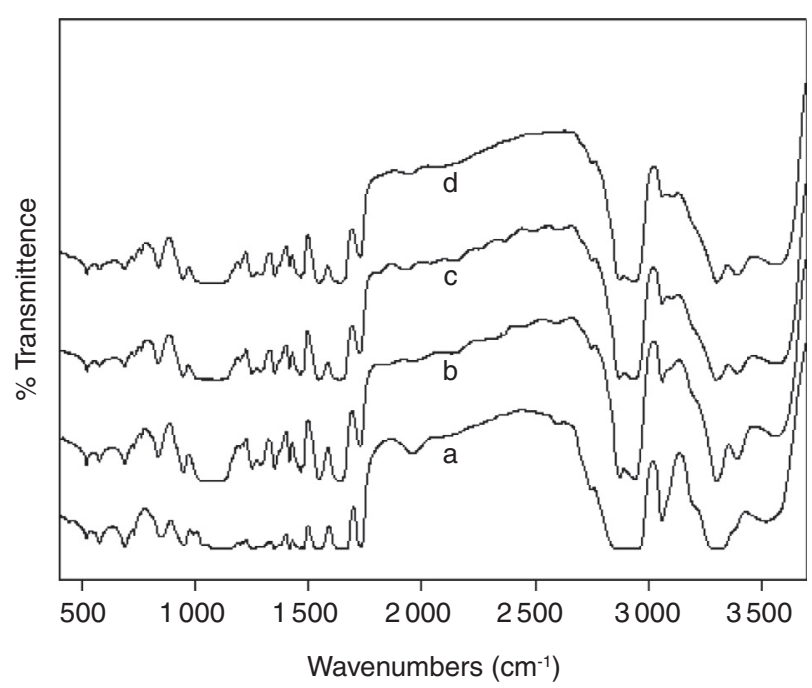

Figure 4

FTIR of a) Pebax, b) 35\% Ag-Pebax, c) 40\% Ag-Pebax and d) $50 \%$ Ag-Pebax membranes.

$\mathrm{C}=\mathrm{O}$ bond due to the electron donation from the $\mathrm{C}=\mathrm{O}$ oxygen to the silver ions. Thus we can conclude that $\mathrm{Ag}$ have interaction with the electron donating sites present in the polymer backbone. The vacant $d$ orbital present in silver is available for binding with the unpaired electrons present in the double bonded $\mathrm{C}_{3} \mathrm{H}_{6}$ olefin leading to П-complexation.

\subsubsection{XRD}

Among the different degrees of loading investigated, $50 \%$ Ag-Pebax membrane was chosen for comparison with the pristine polymer. X-ray diffractograms of Pebax and $50 \%$ Ag-Pebax composite are shown in Figure 5. Both membranes exhibit semicrystalline nature. Pebax (a) is a semicrystalline polymer, which shows narrow diffraction peaks at $14^{\circ}, 27^{\circ}, 54^{\circ}$ and $56^{\circ}$ of $2 \theta$ and the corresponding XRD peaks obtained for Ag-Pebax (b) are broader. This indicates an increase in intersegmental spacing, which may lead to a reduction in degree of crystallinity.

\subsection{Experimental Studies}

\subsubsection{Effect of $\% \mathrm{AgBF}_{4}$ Loading}

Composite membranes were prepared by varying the $\mathrm{AgBF}_{4}$ incorporation in extents of 35,40 and $50 \mathrm{wt} \%$ of the Pebax polymer. As long as the membrane is not exposed to sunlight the permeability results obtained with different samples of the Ag loaded membranes are 
very consistent (reproducible). Table 1 shows the effect of silver loading on permeability and selectivity for $50 / 50 \mathrm{C}_{3} \mathrm{H}_{6}+\mathrm{C}_{3} \mathrm{H}_{8}$ feed mixture at a feed pressure of 4 bar. The authors have carefully peeled off the top layer from the substrates in order to measure the effective thickness for permeability calculation. With increasing $\mathrm{AgBF}_{4}$ loading from $0-50 \mathrm{wt} \%$ of the polymer weight, the permeability enhanced from 7.67 to 99.78 Barrer for $\mathrm{C}_{3} \mathrm{H}_{6}$ and 2.62 to 5.79 Barrer for $\mathrm{C}_{3} \mathrm{H}_{8}$. On the other hand, $50 \mathrm{wt} \%$ Ag-Pebax exhibited higher selectivity of 17.22 , which is nearly five times higher than that of the pristine Pebax membrane. Table 2 exhibits the permeability of Ag-Pebax membranes for $66 / 34 \mathrm{C}_{3} \mathrm{H}_{6}+\mathrm{C}_{3} \mathrm{H}_{8}$ feed mixture at a feed pressure of 2 bar. Selectivity of $\mathrm{C}_{3} \mathrm{H}_{6} / \mathrm{C}_{3} \mathrm{H}_{8}$ enhances with increasing $\mathrm{AgBF}_{4}$ loading

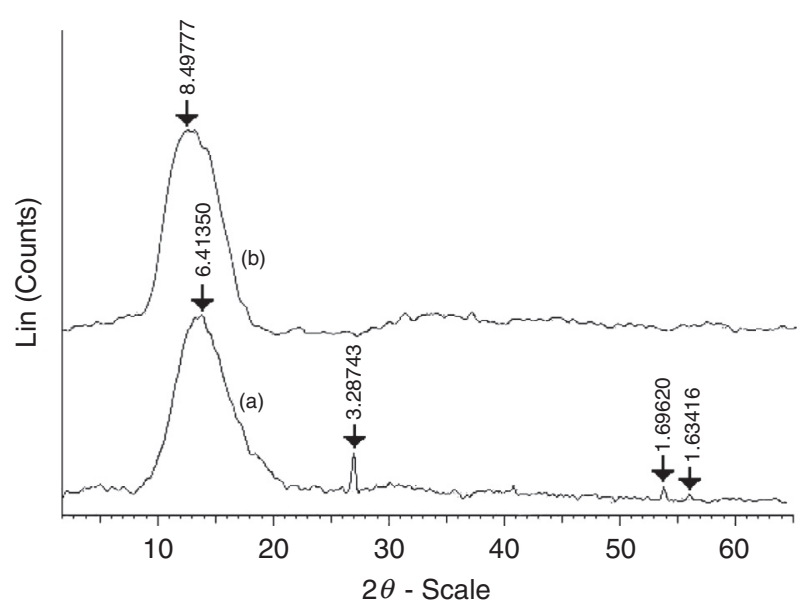

Figure 5

XRD of a) Pebax b) 50\% Ag-Pebax membranes.

TABLE 1

Effect of silver loading in Ag-Pebax membranes on permeability and selectivity for $50 / 50 \mathrm{C}_{3} \mathrm{H}_{6}+\mathrm{C}_{3} \mathrm{H}_{8}$ feed mixture

\begin{tabular}{c|c|c|c|c}
\hline$\% \mathrm{AgBF}_{4}$ & \multirow{2}{*}{$\begin{array}{c}\text { Membrane } \\
\text { thickness } \\
(\mu \mathrm{m})\end{array}$} & \multicolumn{2}{|c|}{$\begin{array}{c}\text { Permeability } \\
\left(\text { Barrer }^{*}\right)\end{array}$} & \multirow{2}{*}{$\begin{array}{c}\text { Selectivity } \\
\left(\mathrm{C}_{3} \mathrm{H}_{6} / \mathrm{C}_{3} \mathrm{H}_{8}\right)\end{array}$} \\
\cline { 3 - 4 } & 15 & 7.7 & 2.6 & \\
\hline 0 & 20 & 31.6 & 6.5 & 4.9 \\
\hline 35 & 25 & 31.8 & 3.1 & 10.1 \\
\hline 40 & 25 & 99.9 & 5.8 & 17.2 \\
\hline 50 & & $\mathrm{C}_{3} \mathrm{H}_{6} \mathrm{H}_{8}$ & \\
\hline
\end{tabular}

1 Barrer $=10^{-10}\left(\mathrm{~cm}^{3}(\mathrm{STP}) . \mathrm{cm} / \mathrm{cm}^{2} . \mathrm{s} . \mathrm{cmHg}\right)$
TABLE 2

Effect of silver loading in Ag-Pebax membranes on permeability and selectivity for $66 / 34 \mathrm{C}_{3} \mathrm{H}_{6}+\mathrm{C}_{3} \mathrm{H}_{8}$ feed mixture

\begin{tabular}{c|c|c|c|c}
\hline \multirow{2}{*}{$\% \mathrm{AgBF}_{4}$} & \multirow{2}{*}{$\begin{array}{c}\text { Membrane } \\
\text { thickness } \\
\end{array}$} & \multicolumn{2}{|c|}{$\begin{array}{c}\text { Permeability } \\
\text { (Barrer) }\end{array}$} & \multirow{2}{*}{$\begin{array}{c}\text { Selectivity } \\
\left(\mathrm{C}_{3} \mathrm{H}_{6} / \mathrm{C}_{3} \mathrm{H}_{8}\right)\end{array}$} \\
\cline { 3 - 4 } & 15 & 3.8 & 1.8 & 2.1 \\
\hline 0 & 20 & 38.9 & 6.3 & 6.2 \\
\hline 35 & 25 & 84.2 & 5.3 & 15.8 \\
\hline 40 & 25 & 123.3 & 6.1 & 20.4 \\
\hline 50 & & & & \\
\hline
\end{tabular}

from 2.11 to 20.38 , which is 8.6 folds higher than pristine Pebax. The permeability for $66 / 34$ is greater than that of $50 / 50 \mathrm{C}_{3} \mathrm{H}_{6} / \mathrm{C}_{3} \mathrm{H}_{8}$ mixture since the higher concentration of the preferentially permeating olefin in the former would lead to greater partial pressure gradient which is the driving force for mass transfer by solution-diffusion mechanism. Moreover, higher numbers of olefin molecules are now available for permeation by carrier mediated transport which is the more prominent route for passage through $\mathrm{AgBF}_{4}$ incorporated membranes.

In pristine Pebax membrane gas transport is solely a function of solubility and diffusivity of the molecules through the polymer matrix. In contrast, gas transport in Ag-Pebax membrane is the combined effect of facilitated transport and solution-diffusion phenomenon. $\mathrm{AgBF}_{4}$ forms temporary bond with $\mathrm{C}_{3} \mathrm{H}_{6}$ and carriers it through the membrane which results in increase of permeability. Upon increasing the $\mathrm{AgBF}_{4}$ loading, the selective nature of Pebax also increases, which is consistent with the concept that $\mathrm{Ag}^{+}$ions increase the cohesive energy density of the matrix. It is believed that $\mathrm{Ag}^{+}$ions could form weak complexes with polar ether groups in the polymer backbone [21]. These complexes act as transient crosslinks that restrict polymer chain mobility, which results in the reduction of diffusion coefficients of non-interacting saturated species like $\mathrm{C}_{3} \mathrm{H}_{8}$. In the specific and reversible $\mathrm{Ag}^{+}-\mathrm{C}_{3} \mathrm{H}_{6}$ molecular interaction, $\mathrm{Ag}^{+}$ions act as carriers for facilitated transport in the membrane and cause carrier mediated transport in addition to the normal transport process. As the $\mathrm{Ag}^{+}$ion concentration increases, large numbers of unsaturated $\mathrm{C}_{3} \mathrm{H}_{6}$ molecule form reversible bonds and pass through the membrane via facilitated transport. On the other hand $\mathrm{C}_{3} \mathrm{H}_{8}$ is rejected by the nonporous $\mathrm{AgBF}_{4}$ filler and therefore it has to follow a tortuous path unlike $\mathrm{C}_{3} \mathrm{H}_{6}$ to reach the downstream side of the membrane. Increase in permeability of $\mathrm{C}_{3} \mathrm{H}_{8}$ might also be anticipated due to an increase in the membrane free volume 
TABLE 3

Performance of different membrane materials for $\mathrm{C}_{3} \mathrm{H}_{6} / \mathrm{C}_{3} \mathrm{H}_{8}$ binary gas mixture separation

\begin{tabular}{|c|c|c|c|c|}
\hline Membrane & $\begin{array}{c}\mathrm{C}_{3} \mathrm{H}_{6} / \mathrm{C}_{3} \mathrm{H}_{8} \\
\text { binary mixture }\end{array}$ & Pressure (bar) & Selectivity & References \\
\hline $\mathrm{EC}$ & $55 / 45$ & $3-3.9$ & 3.2 & [6] \\
\hline $\mathrm{CA}$ & $55 / 45$ & $3-3.9$ & 2.6 & [6] \\
\hline PSF & $55 / 45$ & $3-3.9$ & 1.4 & [6] \\
\hline $\mathrm{POZ} / \mathrm{AgNO}_{3} / \mathrm{AgCF}_{3} \mathrm{SO}_{3}$ & $50 / 50$ & 0.02 & 28 & {$[6]$} \\
\hline $\mathrm{POZ} / \mathrm{AgBF}_{4} / \mathrm{AgCF}_{3} \mathrm{SO}_{3}$ & $50 / 50$ & 0.02 & 23 & [6] \\
\hline Poly(ethylene-co-propylene) / $62 \% \mathrm{AgBF}_{4}$ & $50 / 50$ & & 55 & [9] \\
\hline PAEK/Azide (carbonaceous membrane) & $50 / 50$ & 6 & 32 & [22] \\
\hline ZIF-8 (zeolite membrane) & $50 / 50$ & 1 & 28 & [23] \\
\hline ZIF-8/6FDA-DAM & $50 / 50$ & 0.037 & 15.5 & [24] \\
\hline Pebax $1657 / 50 \% \mathrm{AgBF}_{4}$ & $50 / 50$ & 4 & 17.2 & This study \\
\hline Pebax $1657 / 50 \% \mathrm{AgBF}_{4}$ & $66 / 34$ & 2 & 20.2 & This study \\
\hline
\end{tabular}

by the gas molecules permeating first which in turn make the flow of the next kind relatively easier.

Researchers had developed facilitated transport membranes with different grades of Pebax for olefin-paraffin separation. Muller et al. [16] had studied performance of Pebax 2533 (constituted by $20 \%$ amide groups) and Pebax 4011 (constituted by $43 \%$ amide groups) embedded with $\mathrm{AgClO}_{4}$ salt, for which selectivities of 110 to 190 were observed with humidified equimolar ethane/ ethylene gas mixture. Wang et al. [17] synthesized facilitated transport membrane by coating $\mathrm{AgBF}_{4}$ over defect free Pebax 2533 membrane for $\mathrm{C}_{3} \mathrm{H}_{6} / \mathrm{C}_{3} \mathrm{H}_{8}$ separation. In the present work, $\mathrm{AgBF}_{4}$ loaded Pebax 1657 (constituted by $40 \%$ amide groups) shows mixture selectivity of 17.2 with equimolar $\mathrm{C}_{3} \mathrm{H}_{6} / \mathrm{C}_{3} \mathrm{H}_{8}$ gas mixture. Lesser selectivity in mixture gas is due to the coupling effect and absence of any humidification. Table 3 compares performance of different membrane materials for $\mathrm{C}_{3} \mathrm{H}_{6} / \mathrm{C}_{3} \mathrm{H}_{8}$ binary gas mixture separation.

\subsubsection{Effect of Feed Composition}

Figure 6 illustrates the effect of $\mathrm{C}_{3} \mathrm{H}_{6}$ concentration in the binary feed mixture on the performance of the indigenously synthesized membrane. Since $50 \%$ Ag-Pebax membrane shows better performance, it was chosen to study the effect of feed composition at a constant pressure of 2 bar. Compositions of feed, permeate and retentate streams were analyzed consecutively with an online gas chromatograph. With $50 \%$

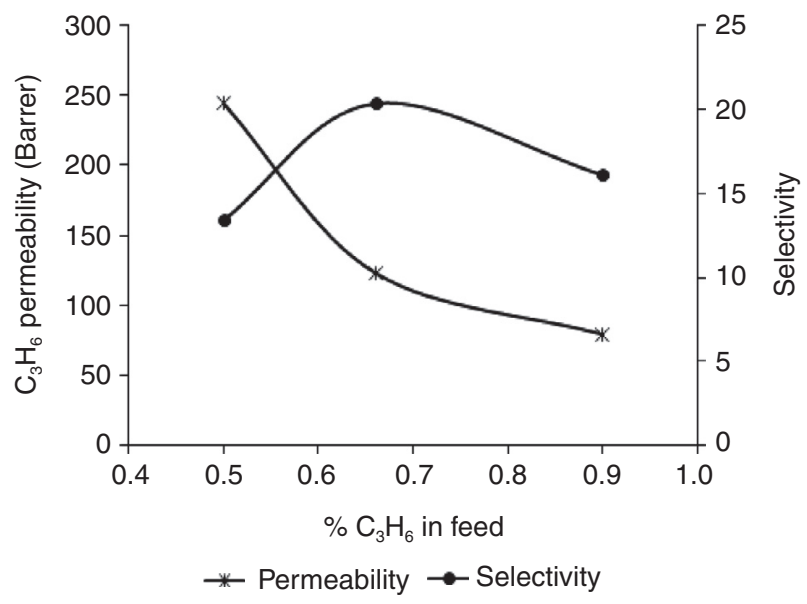

Figure 6

Effect of feed composition on $\mathrm{C}_{3} \mathrm{H}_{6}$ permeance and selectivity for $50 \%$ Ag-Pebax membrane at a pressure of 2 bar.

Ag loaded Pebax membrane, $50 \% \mathrm{C}_{3} \mathrm{H}_{6}$ feed mixture gives $78.5 \% \quad \mathrm{C}_{3} \mathrm{H}_{6}$ in permeate whereas $66 \% \mathrm{C}_{3} \mathrm{H}_{6}$ feed mixture gives $92.9 \% \mathrm{C}_{3} \mathrm{H}_{6}$ and $90 \% \mathrm{C}_{3} \mathrm{H}_{6}$ feed mixture gives a permeate containing $98.6 \% \quad \mathrm{C}_{3} \mathrm{H}_{6}$. As the $\mathrm{C}_{3} \mathrm{H}_{6}$ composition in feed is increased from 50 to $90 \%$, permeability decreases from 244.3 to 79.2 Barrer. Mixture gas selectivity varies from 13.4 to 16.9 and attains a maximum of 20.4 at $66 \% \quad \mathrm{C}_{3} \mathrm{H}_{6}$ 


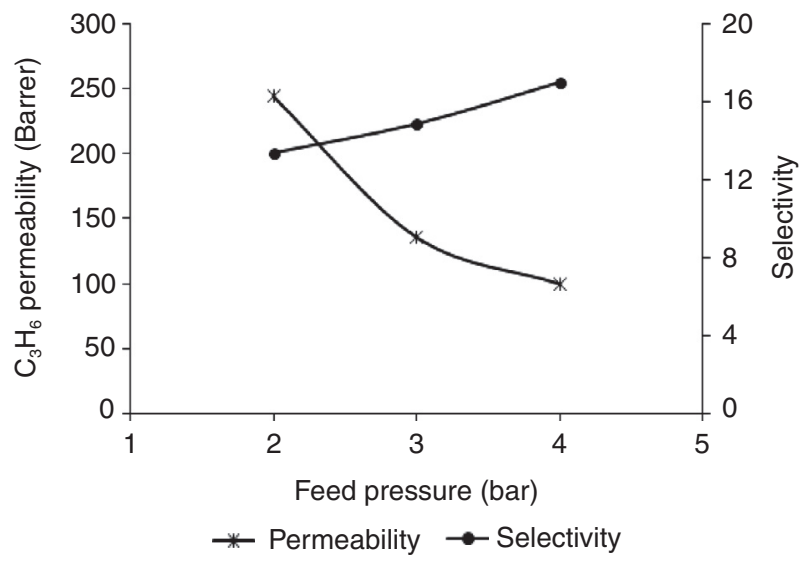

Figure 7

Effect of feed pressure on $\mathrm{C}_{3} \mathrm{H}_{6}$ permeance and selectivity for $50 \%$ Ag-Pebax membrane using $50 \% \mathrm{C}_{3} \mathrm{H}_{6}$ feed mixture.

feed mixture. Reduction in permeability might be due to limited number of sorption sites and transport passage ways available in the membrane. At higher feed $\mathrm{C}_{3} \mathrm{H}_{6}$ concentrations, the sorption sites and silver salt in the Ag-Pebax membrane might get saturated, which could result in a reduction in permeability due to absence of carrier mediate transport.

\subsubsection{Effect of Pressure}

Figure 7 shows the effect of pressure (2-4 bar) on the performance of $50 \% \mathrm{Ag}$-Pebax composite membrane with the feed mixture of $50 \% \mathrm{C}_{3} \mathrm{H}_{6}$. Increasing feed pressure results in gradual increase of selectivity from 13.4 to 17.2 whereas permeance decreases from 244.3 to 99.8 Barrer. Presence of fixed sorption sites in the membrane enhances the uptake of pure gas molecules with rising feed pressure. However, the existence of even a small amount of $\mathrm{C}_{3} \mathrm{H}_{8}$ in the feed alters the permeability due to coupling effect. During permeation of binary gas mixture, the presence of one gas may affect the permeation of the other through transfer of momentum leading to dragging of less permeable gas through the barrier, which is called coupling effect [25]. For pure propylene permeation, the membrane permeability is determined by the interactions between propylene molecules and the membrane material. Compared to propylene, propane is a slow gas. When propane is present, the permeation is complicated by competitive sorption and coupled transport between the two feed components resulting in greater free volume and reduced selectivity.

\section{CONCLUSIONS}

The present study demonstrated the feasibility of preparing TFC membrane of Pebax as well as Ag-Pebax on PES support for $\mathrm{C}_{3} \mathrm{H}_{6} / \mathrm{C}_{3} \mathrm{H}_{8}$ separation. Experiments were conducted with three feed mixtures, in which $\mathrm{C}_{3} \mathrm{H}_{6}$ is $50 \%, 66 \%$ and $90 \%$ and the remaining is $\mathrm{C}_{3} \mathrm{H}_{8}$. Membranes were physically modified by incorporating 35, 40 and $50 \%$ of $\mathrm{AgBF}_{4}$ to facilitate the transport of $\mathrm{C}_{3} \mathrm{H}_{6}$. SEM revealed complete dissolution of silver salt within the polymer solution. Characterization by XRD and FTIR showed $\mathrm{Ag}^{+}$ions induced weak physical interactions within the polymer matrix. Increasing the percentage of $\mathrm{Ag}^{+}$incorporation improved the separation performance of membranes. It was found that the selectivity and permeability of the membrane with respect to $\mathrm{C}_{3} \mathrm{H}_{6}$ improved with increasing feed concentration of the gas due to greater partial pressure gradient. A hybrid process combining membrane separation and distillation would make production of polymer grade propylene in refineries technically feasible, more economical and safe due to reduction in number of distillation trays in the lengthy $\mathrm{C}_{3}$ splitter.

\section{ACKNOWLEDGMENTS}

The first author R. Surya Murali is grateful to the Council of Scientific and Industrial Research (CSIR), New Delhi, India for funding his Ph.D. research programme under GATE-JRF scheme. The corresponding author acknowledges the financial support from CSIR under their XII Five Year Plan MATES project.

\section{REFERENCES}

1 Maryam A., Tahereh K., Mohammad R. (2008) A review on olefin/paraffin separation using reversible chemical complexation technology, Journal of Industrial and Engineering Chemistry 14, 5, 622-638.

2 Grande C.A., Rodrigues A.E. (2005) Propane/propylene separation by pressure swing adsorption using zeolite 4A, Industrial and Engineering Chemistry Research 44, 88158829.

3 Faiz R., Li K. (2012) Olefin/paraffin separation using membrane based facilitated transport/ chemical absorption techniques, Chemical Engineering Science 73, 261-284.

4 Pettersen T., Argo A., Noble R.D., Koval C.A. (1996) Design of combined membrane and distillation processes, Separation Technology 6, 3, 175-187.

5 Stephan W., Noble R.D., Koval C.A. (1995) Design methodology for a membrane/distillation column hybrid process, Journal of Membrane Science 99, 3, 259-272.

6 Burns R.L., Koros W.J. (2003) Defining the challenges for $\mathrm{C}_{3} \mathrm{H}_{6} / \mathrm{C}_{3} \mathrm{H}_{8}$ separation using polymeric membranes, Journal of Membrane Science 211, 2, 299-309. 
7 Kim J.H., Park S.M., Won J., Kang Y.S. (2005) Unusual separation property of propylene/propane mixtures through polymer/silver complex membranes containing mixed salts, Journal of Membrane Science 248, 1-2, 171-176.

8 Lee D.H., Kang Y.S., Kim H.J. (2009) Olefin separation performances and coordination behaviors of facilitated transport membrane based on poly (styrene- $b$-isoprene- $b$ styrene)/silver salt complexes, Macromolecular Research 17, 2, 104-109.

9 Kim J.K., Min B.R., Kim Y.W., Kang S.W., Won J., Kang Y.S. (2007) Novel composite membranes comprising silver salts physically dispersed in poly(ethylene-co-propylene) for the separation of propylene/propane, Macromolecular Research 15, 4, 343-347.

10 Joo S.H., Kim J.H., Kang S.W., Jang J., Kang Y.S. (2007) Propylene sorption and coordinative interactions for poly (N-vinyl pyrrolidone-co-vinyl acetate)/silver salt complex membranes, Journal of Polymer Science Part B: Polymer Physics 45, 16, 2263-2269.

11 Susheela B., Sridhar S., Khan A.A. (2000) Recovery of propylene from refinery off-gas using metal incorporated ethylcellulose membranes, Journal of Membrane Science 174, 1, 67-69.

12 Sridhar S., Khan A.A. (1999) Simulation studies for the separation of propylene and propane by ethylcellulose membrane, Journal of Membrane Science 159, 1-2, 209-219.

13 Sunderrajan S., Freeman B.D., Hall C.K., Pinnau I. (2001) Propane and propylene sorption in solid polymer electrolytes based on poly(ethylene oxide) and silver salts, Journal of Membrane Science 182, 1-2, 1-12.

14 Kim J.H., Min B.R., Won J., Joo S.H., Kim H.S., Kang Y. S. (2003) Role of polymer matrix in polymer/silver complexes for structure, interaction, and facilitated olefin transport, Macromolecules 36, 16, 6183-6188.

15 PEBAX-Basis of Performance, Polyether Block Amide, Elf Atochem Technical Document, Paris, France.

16 Muller J., Peinemann K.V., Muller J. (2002) Development of facilitated transport membranes for the separation of olefins from gas streams, Desalination 145, 1-3, 339-345.
17 Wang Y., Ren J., Deng M. (2011) Ultrathin solid polymer electrolyte PEI/Pebax2533/AgBF 4 composite membrane for propylene/propane separation, Separation and Purification Technology 77, 1, 46-52.

18 Ferraz H.C., Duarte L.T., Alves M.D.T.L.M., Habert A.C., Borges C.P. (2007) Recent achievements in facilitated transport membranes for separation processes, Brazilian Journal of Chemical Engineering 24, 1, 101-118.

19 Hamouda S.B., Quang T.N., Dominique L., Sadok R. (2008) Facilitated transport of ethylene in poly(amide12block tetramethylenoxide) copolymer $/ \mathrm{AgBF}_{4}$ membranes containing silver (I) and copper (I) ions as carriers, Journal of Applied Sciences 8, 7, 1310-1314.

20 Surya Murali R., Sridhar S., Sankarshana T., Ravikumar Y.V.L. (2010) Gas permeation behavior of Pebax-1657 nanocomposite membrane incorporated with multiwalled carbon nanotubes, Industrial and Engineering Chemistry Research 49, 14, 6530-6538.

21 Merkel T., Blanc R., Zeid J., Suwarlim A., Firat B., Wijmans H., Asaro M., Greene M. (2007) Separation of olefin/paraffin mixtures with carrier facilitated membranes, Project DE-FC36 04GO14151.

22 Yeom C.K., Lee S.H., Lee J.M. (2000) Study of transport of pure and mixed $\mathrm{CO}_{2} / \mathrm{N}_{2}$ gases through polymeric membranes, Journal of Applied Sciences 78, 179-189.

23 Chng M.L., Xiao Y., Chung T.S., Toriida M., Tamai S. (2009) Enhanced propylene/propane separation by carbonaceous membrane derived from poly(aryl ether ketone)/ 2,6-bis(4-azidobenzylidene-4-methyl-cyclohexanoneinterpenetrating network, Carbon 47, 7, 1857-1866.

24 Pan Y., Li T., Lestari G., Lai Z. (2012) Effective separation of propylene/propane binary mixtures by ZIF-8 membranes, Journal of Membrane Science 390-391, 93-98.

25 Zhang C., Dai Y., Johnson J.R., Arvan O., Koros W.J. (2012) High performance ZIF-8/6FDA-DAM mixed matrix membrane for propylene/propane separations, Journal of Membrane Science 389, 34-42.

Manuscript accepted in September 2013 Published online in January 2014

Cite this article as: R. Surya Murali, K. Yamuna Rani, T. Sankarshana, A.F. Ismail and S. Sridhar (2015). Separation of Binary Mixtures of Propylene and Propane by Facilitated Transport through Silver Incorporated Poly(Ether-Block-Amide) Membranes, Oil Gas Sci. Technol 70, 2, 381-390. 